\title{
Factors shaping the Venice Charter and its usefulness - on the example of heritage protection in Poland
}

\section{Bogusław Szmygin}

https://orcid.org/0000-0003-0629-4495

b.szmygin@pollub.pl

\section{Olga Skoczylas \\ https://orcid.org/0000-0001-6586-9207 \\ o.skoczylas@pollub.pl}

Faculty of Civil Engineering and Architecture,Lublin University of Technology

\begin{abstract}
Summary: In the collection of dozens of doctrinal documents on the protection of heritage, the Venice Charter occupies a unique position. The Venice Charter was created more than half a century ago, but it is still treated as the universal, basic document of the heritage protection. This is confirmed by numerous declarations emphasizing the validity of the Venice Charter, contained in many doctrinal documents adopted by ICOMOS, and even in the Operational Guidelines of the UNESCO World Heritage Committee. The Venice Charter is therefore a kind of decalogue for the monument protection [1]. However, every few years there are discussions whether Venice Charter still retains this position. This problem is not resolved unequivocally. However, in the twenty-first century, it can be stated that Venice Charter is not an universal document and cannot be a document shaping the entire heritage protection. This is shown by the reception of the Venice Charter by the Polish conservation community over the past decades. The change of the Venice Charter position is particularly clear in the context of the system transformation that took place as a result of the fall of communism in 1989. This change shows well that doctrinal documents of the heritage protection reflect the external conditions in which they are created. Their importance and usefulness is in principle limited to specific conditions and a specific group of heritage. This is also how the Venice Charter should be treated.
\end{abstract}

Keywords: heritage, factors, protection, UNESCO, Venice Charter

\section{Factors shaping the Venice Charter as a product of a certain time}

The Venice Charter was adopted and written during the IInd International Congress of Architects and Technicians of Historic Monuments in Venice in 1964 [2]. However, the ideas expressed in it are not only the views of its authors, but above all reflecting the situation shaping the protection of heritage at that time. Three factors can be identified as leading.

First of all, the 60 s were a period when the international community believed in the possibility of cooperation and even mutual assistance. It was, of course, a period of division of the whole world into two hostile systems - capitalism and communism - but the post-war culmination of this conflict has already passed. In the early $60 \mathrm{~s}$, international cooperation in various areas began, including actions aiming saving the endangered monuments. The most well-known example of such actions was the rescue of Egyptian temples in Abu Simbel, for which funds were transferred by 50 countries. There were more similar actions, including saving monuments after the great flood in Venice, or helping to save Buddhist temples in Borobudur. The Venice Conference and beginning of the work that led to the adoption of the UNESCO World Heritage Convention were proof and effect of the prevailing belief in the possibility of international cooperation for the heritage protection. 
At that time, the international conservation community wanted to believe that heritage was the common heritage of all humanity and should be protected together. This is confirmed by the famous beginning of the Venice Charter text - People are becoming more and more conscious of the unity of human values and regard ancient monuments as a common heritage. The common responsibility to safeguard them for future generations is recognized. In such an atmosphere, it was necessary to create a document that would treat the problem of heritage protection as a whole. Therefore, such a document could not take into account the differences dividing, for example, typological groups of monuments or significant differences between monuments in individual regions of the world. The lack of reflection on the specificity of non-European heritage was also due to the very small representation of non-European countries in Venice (there were representatives of only 3 countries outside Europe signed under the Venice Charter).

The second important factor shaping the Venice Charter was the specific situation of monument protection in the 60s. At that time, post-war programs for the reconstruction of monuments were ending. It should be remembered that due to the enormous destruction of many countries, reconstruction programs had to dominate the post-war monuments protection. The enormous destruction of the war meant that many monuments needed to be rebuilt - not conserved, not restored. These actions were costly and took a long time. This situation was in Poland where the historical centre of Warsaw was completely destroyed. The reconstruction programs have been carried out in many historic cities. Historic fortification are always protected according to the strict conservation rules (Fig. 1).

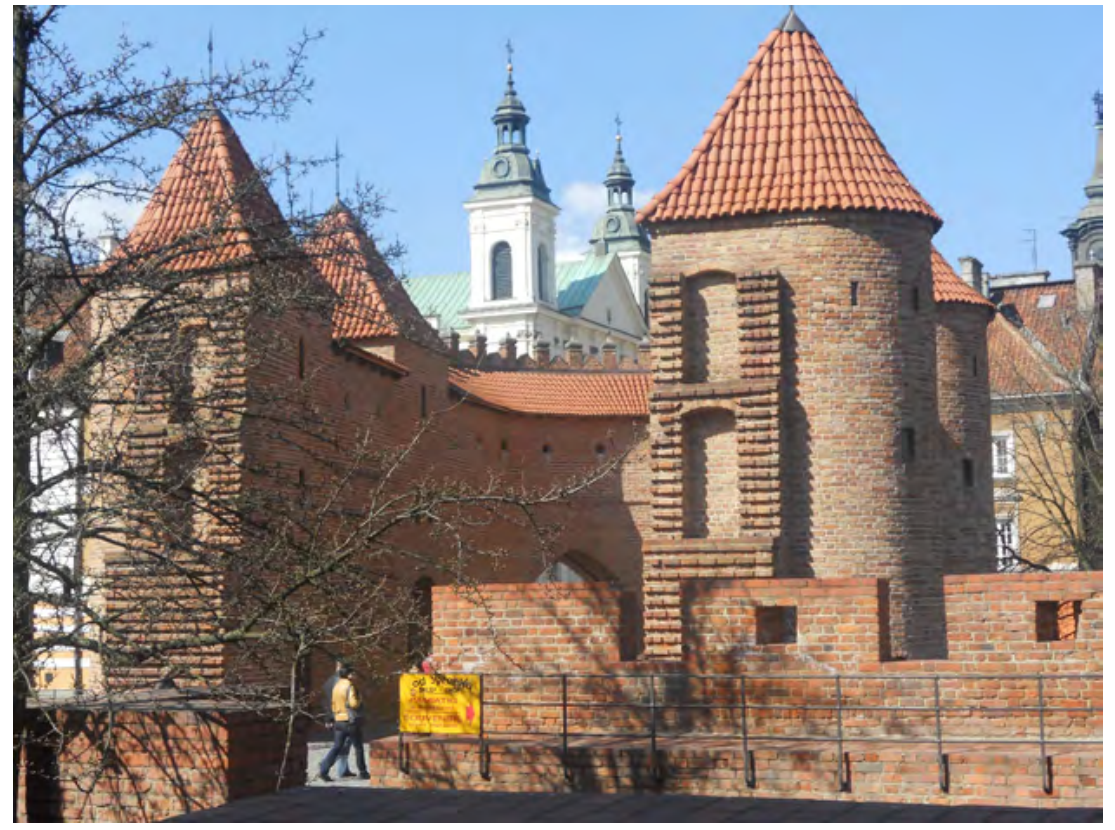

Fig. 1. Starówka in Warsaw photography by B. Szmygin

The reconstruction of monuments destroyed during the war meant the resignation from pre-war conservation principles [3]. Before World War II, conservators unequivocally recognized that monuments should only be preserved, and ruined monuments should not be rebuilt. For example, such decisions were accepted during Congresses of Conservators in Poland. However, due to the enormous destruction of the war, conservators had to suspend their views and rebuild monuments. Therefore, the congress of conservators in Paris in 1957 at which delegates from European countries presented their experiences in post-war monuments rebuilding/ reconstruction, did not deal with the conservation doctrine, did not repeal the common document.

It was only in the 60 s that it could be considered that the main post-war reconstructions were completed (in practice, in many cities they are still going on today). It was possible to return to the proper rules of dealing with monuments - to protection and conservation. The Venice Charter is a declaration of return to such principles. That is why the scope of permitted conservation works - conservation, restoration, anastylosis - is so clearly emphasized. Therefore, reconstruction is also so clearly excluded. 
The third factor shaping the Venice Charter was the understanding of the concept of an architectural monument, which was obligated at that time. The architectural monument - which was primarily concerned by the Venice Charter - was understood similarly to a work of art and a historic document. The exceptional value of the monument understood in this way justified its exceptional treatment - preservation in the minimum transformed historical form. Therefore, interference in the historical object should be limited as possible.

Such an understanding of the monument also resulted from the education and professional experience of the authors of the Venice Charter. An important position among them was occupied by Italian and French conservators who dealt with works of art. This approach could be applied to valuable architectural objects. As a consequence, in the Venice Charter, architectural monuments were treated similarly to works of art - the need for maximum protection of the historical form and substance of the monument was written. This was also possible because the Venice Charter was not about the protection of historic cities.

These three factors defined the rigorous and idealistic approach to monument protection set out in the Venice Charter.

\section{Determinants of monument protection in Poland after World War II}

In Poland, the reception and attitude to the Venice Charter were shaped by the specific conditions in which the protection of monuments was carried out after World War II.

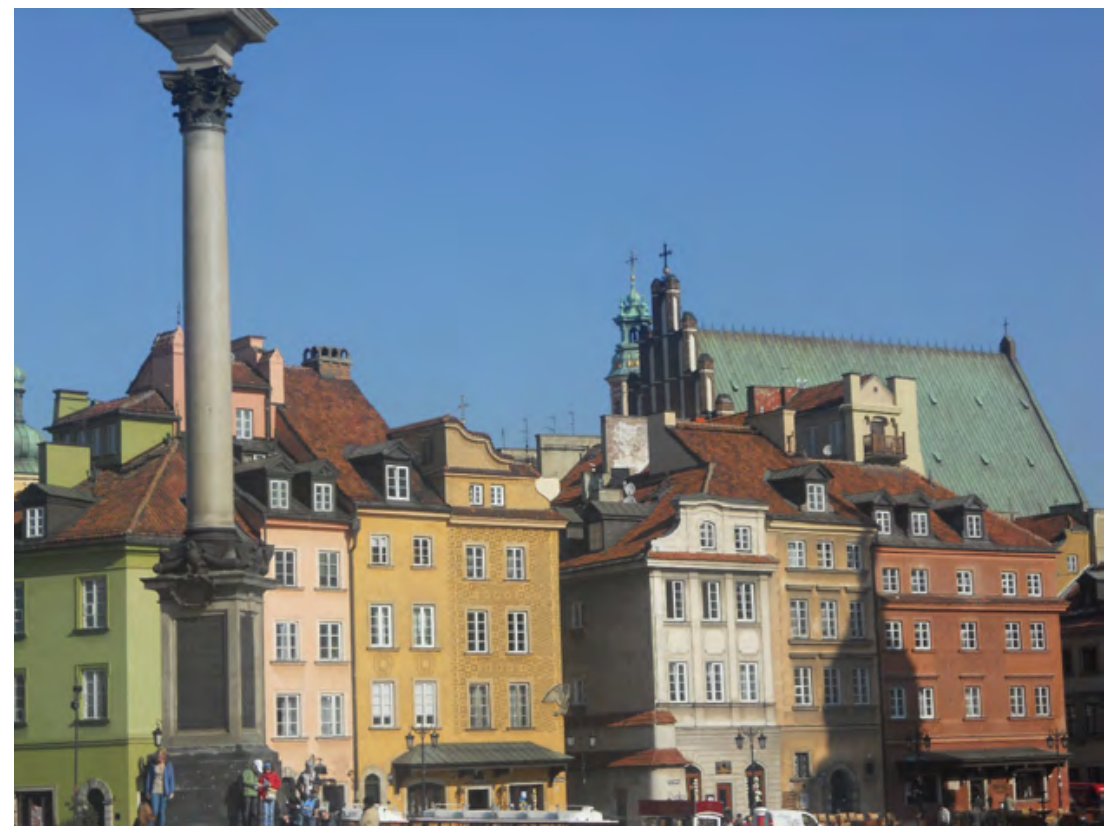

Fig. 2. Historic center of Warsaw - photography by B. Szmygin

The main factor that determined the treatment of monuments in Poland was the huge destruction of the war [4]. Of great importance was the deliberate destruction of Warsaw, which was a symbol of the German barbarian directed against the Polish heritage. The reconstruction of the Old Town in Warsaw, which was destroyed in $90 \%$, was a task supported by the whole nation. Therefore, the new authorities (as a result of the war, a new political system was introduced in Poland) considered the program of reconstruction of monuments as an important, propaganda task. In addition, socialist-realism (politically conditioned architectural style) used traditional and national forms - historical objects were considered as such historic centre of capital of Poland was intentionally destroyed by German troops, therefore, rebuilding in historic shape was symbol of nation victory. Historic buildings were rebuild in the most valuable forms from XVIII Century (Fig. 2). The historical reconstruction program was used in the rebuilding of many destroyed former German cities, which after the war were attached to the Poland - Gdańsk, Szczecin, Wrocław, etc. In the reconstruction of historical complexes, a 
traditional, conservative approach to the protection of monuments could not was used. Therefore, Gdańsk after the completion of the reconstruction program, strict conservation rules were willingly adopted by the conservation community. In Gdańsk buildings rebuild in 80 . and 90. are new version of the historic patterns (Fig. 3). The picture presenting the Tenement houses in Zamośc. Town Hall in Zamość is a Symbol of Renaissance Ideal Town. Systematic protection started before the II WW (Fig. 4).
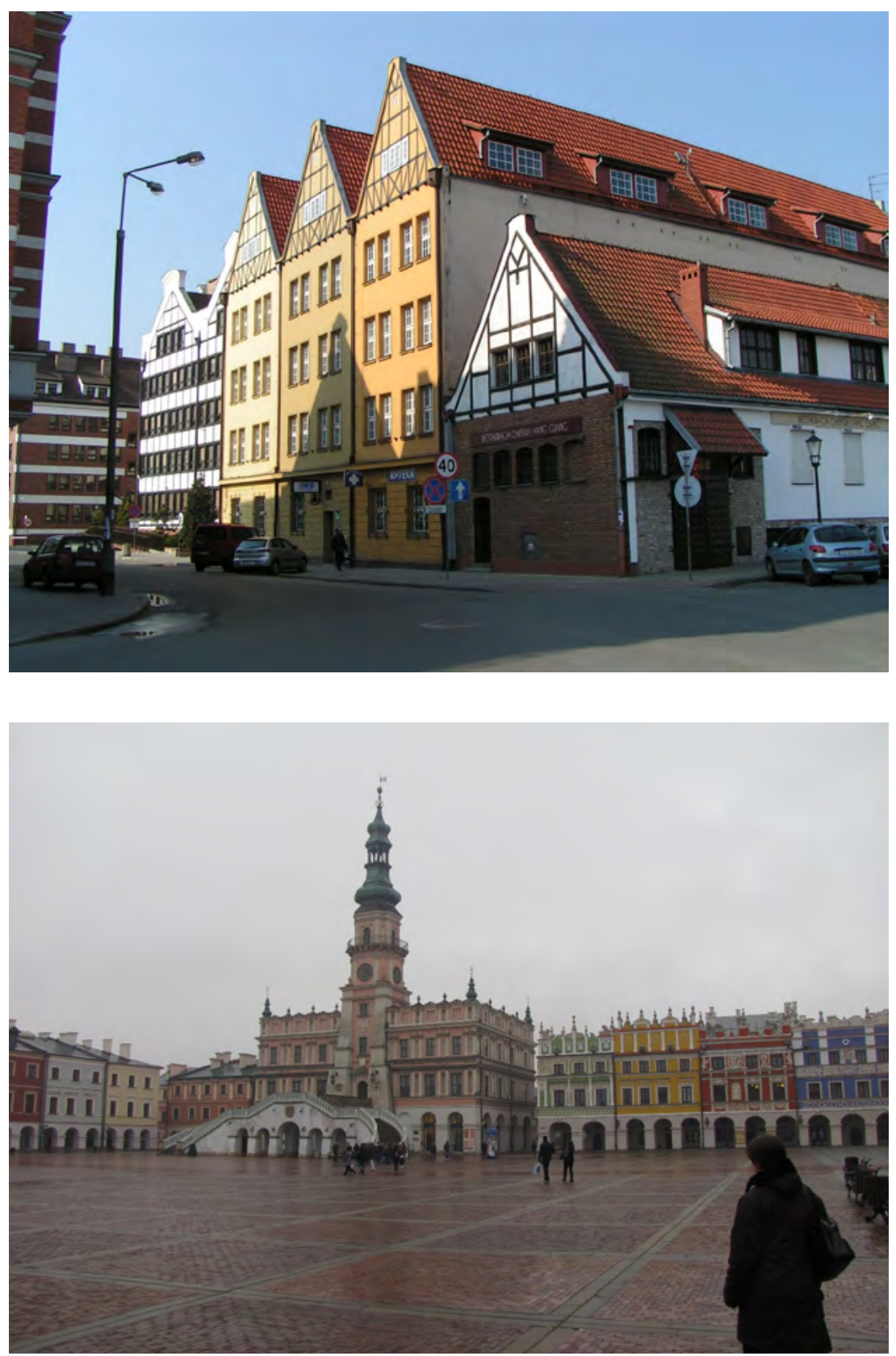

Fig. 3. Old town in Gdańsk photography by B. Szmygin
Fig. 4. Town Hall in Zamość photography by B. Szmygin

An important factor supporting a uniform and centrally controlled approach to monuments was the new political and economic system. In Poland, private property has been very limited. Palaces, manors, tenement houses, public buildings were state property. At the same time, the organization of works on historic buildings was centralized. One large, monopolistic enterprise was organized, which carried out repairs and maintenance of historical buildings throughout the country. These works were publicly funded. 
In Poland, a unique system was created, in which historical objects owned by the state were renovated and maintained with state funds, and conservation works were carried out by a state-owned, specialized enterprise. In such conditions, it was also possible to adapt the utility function to the historical character of the building.

Of course, it cannot be said that this was a good system of monument protection. This system was burdened with all the flaws of the socialist system. First of all, it worked too slowly, did not provide good quality work, was not very efficient. Therefore, in many historic buildings - especially of lesser value - conservation works were not carried out and their technical condition deteriorated.

The centrally managed, state system of monument protection also consisted in limiting the number of protected historical objects. At the beginning of the $60 \mathrm{~s}$, a team of several specialists analysed and evaluated the entire collection of historical objects in Poland. About 36 thousand historical objects were selected, which were divided into 5 classes. The protection of the state was focused primarily on the 3 most valuable classes of objects, of which there were only 7 thousand. A relatively small but valuable collection of monuments was protected in accordance with the strict conservation rules set out in the Venice Charter - protection of historic substance and form, new additions in contemporary forms, preservation of the historic function.

The program presented in Venice Charter was widely accepted by the Polish conservation community. This was mainly due to the external conditions in which the protection of monuments took place - a centrally managed system of monument protection. The idealistic approach to heritage protection also resulted from the recognition (in Poland and abroad) of the post-war reconstruction programs of historic cities. Undoubtedly, the active participation of Polish conservators in the Venetian Congress and the fact that in Poland in 1965 ICOMOS - the most important international organization of conservators - was founded, was also important. The Venice Charter was the doctrinal foundation of ICOMOS.

As a consequence, the Venice Charter was recognized by Polish conservators as the basic document for the protection of historic objects.

\section{Determinants of monument protection in Poland after the change of the system (the fall of communism)}

In 1989, the communist system collapsed in Poland and the process of transformation of the system towards a liberal market economy and democracy began. This also meant a complete change in the factors shaping the protection of monuments.

The change of the political and economic system in Poland led to a thorough change in the system of monument protection. Elements of the monument protection system must be congruent with foundations of the political and economic system functioning in a specific country [5]. For this reason, when a political system changes, foundations of a monument protection system change as well. It is certainly a long-lasting process which results from the nature of political system transformation. Significance of changes in the most important elements characteristic to the monument protection system in Poland have been provided in the Comparison of monument protection systems (Table 1 ).

Description of changes introduced after 1989 into the Polish monument protection system [6]composed of 25 plates, was arranged by the Department of Movable Monuments at the National Centre for Monuments Study and Documentation (KOBiDZ proves that these changes are compliant with the general direction of transformations taking place in the contemporary heritage protection. ${ }^{1}$

Changes occurring in Poland result in historic monuments and sites being privatised and responsibility for these assets being shifted to private owners who are also accountable for financing protection works. These processes therefore result in commercialising the protection and use of historic monuments and sites. Consequently, the number of transformations resulting from modernisation, functionality, and aesthetics increases - so as their scope. This, however, exerts negative impact on authenticity and integrity, i.e. fundamental elements whose presence influences the value of historic monuments and sites as pieces of evidence of historical

1 The aforementioned description does not, however, prove that the monument protection system applied in the Polish People's Republic was better; it contained a number of defects which wielded adverse influence on the way it functioned. The comparison is aimed at emphasising profound differences between the systems presented as well as at showing the direction of development of the monument protection system stemming from the political transformation in Poland. 
significance. Multi-aspect privatisation involving also programme-based limitations of both liability and the role that state authorities play in monument protection results in conservation officers losing their control.

An additional factor shaping the situation in the protection of monuments was a very significant increase in their number. Currently, there are over 80,000 different buildings and urban areas in the register of monuments in Poland. The diversity of typological groups of monuments has also increased significantly [7]what implication does it hold for urban planners? This paper describes a study on the perception of city images using a combination of "big data" and "small data" methods in the Tri-City Region in Poland. The aims were to 1.

In the changed conditions, the way of operation of historic buildings must be very diverse. Conservation activities can no longer be limited to conservation and restoration (as recommended by the Venice Charter). Conservators must adapt to such conditions and formulate a adjusted conservation theory.

Modern conservation theory cannot be universal, it must be fragmented. For different groups of typological monuments and for the protection of monuments in different regions, separate rules of operation are created taking into account their specificity [8]. That is why dozens of specialized doctrinal texts are currently being written. In Poland, for example, in recent years, the Charter for the Protection of Historical Ruins or the Charter for the Protection of Fortifications have been developed [9]. The Venice Charter is already just one of many doctrinal documents that applies to a small group of historical buildings of the greatest value [10].

Table 1. Comparison of monument protection systems in Poland /before and after the political transformation/

\section{Features characteristic to the system (comparison criteria)}

Form of ownership (the prevailing and the preferred one)

\section{Responsibility for historic monuments and sites}

Sources of financing

\section{Status of the historic monument or site}

Attitude of the conservation service

The role of the conservation office
The former system (before 1989)

state ownership

state authorities are responsible for preserving properties of historical significance

state authorities provide financial means for the monument protection system

historic monuments or sites are not perceived as commercial assets providing funds for their preservation or maintenance is not considered an investment

conservation officers implement state's central policy

conservation officers are active define the forms of protecting and using historic monuments and sites
The current system (after 1989)

private ownership

owner and user of a historic monument or site are statutorily responsible for the asset

owners and users of a historic monument or site are responsible for providing financial means

historic monuments or sites are perceived as commercial assets providing funds for their preservation or maintenance is considered an investment

conservation officers are not independent (they operate within Regional Offices and City Corporations).

conservation officers are passive initiatives are undertaken either by owners of historic monuments and sites or by investors. 


\section{References}

[1] Jeleński T., Practices of Built Heritage Post-Disaster Reconstruction for Resilient Cities, Buildings, t. 8, nr 4, Art. nr 4, kwi. 2018, doi: 10.3390/buildings8040053.

[2] Zhiwen H., The Venice Charter: International Charter for the Conservation and Restoration of Monuments and Sites (1964), sty. 17, 2016, http://orcp.hustoj.com/venice-charter-1964/ (dostęp grudz. 21, 2021).

[3] Pabijan M., Palomar García G., Flores Antunes B., Antoł W., Zieliński P., Babik W., Evolutionary principles guiding amphibian conservation, Evol. Appl., t. 13, nr 5, 2020, doi: 10.1111/eva.12940.

[4] Fuglewicz S., System stużb ochrony zabytków w Polsce a społeczna partycypacja w ochronie zabytków, Prot. Cult. Herit., nr 1, Art. nr 1, maj 2016, doi: 10.24358/ODK_2016_01_05.

[5] Gyurkovich M., Gyurkovich J., New Housing Complexes in Post-Industrial Areas in City Centres in Poland Versus Cultural and Natural Heritage Protection-With a Particular Focus on Cracow, Sustainability, t. 13, nr 1, Art. nr 1, sty. 2021, doi: 10.3390/su13010418.

[6] Pielas M., To learn - to value - to protect. The role of documenting cultural heritage in the construction of social support for the idea of the protection of historical monuments, Muzealnictwo, t. 47, s. 129-135, 2006.

[7] Huang J., Obracht-Prondzynska H., Kamrowska-Zaluska D., Sun Y., Li L., The image of the City on social media: A comparative study using "Big Data" and "Small Data" methods in the Tri-City Region in Poland, Landsc. Urban Plan., t. 206, s. 103977, luty 2021, doi: 10.1016/j.landurbplan.2020.103977.

[8] Forrest C., International Law and the Protection of Cultural Heritage. London: Routledge, 2009. doi: 10.4324/9780203865194.

[9] Merryman J.H., Protection of the Cultural Heritage, Am. J. Comp. Law Suppl., t. 38, s. 513, 1990.

[10] Ferretti V., Bottero M., Mondini G., Decision making and cultural heritage: An application of the Multi-Attribute Value Theory for the reuse of historical buildings, J. Cult. Herit., t. 15, nr 6, s. 644-655, lis. 2014, doi: 10.1016/j.culher.2013.12.007. 